\title{
Sighting characteristics and photo-identification of Cuvier's beaked whales (Ziphius cavirostris) near San Clemente Island, California: a key area for beaked whales and the military?
}

\author{
Erin A. Falcone · Gregory S. Schorr • Annie B. Douglas • \\ John Calambokidis · Elizabeth Henderson • \\ Megan F. McKenna · John Hildebrand · David Moretti
}

Received: 13 October 2008/ Accepted: 18 August 2009/Published online: 1 September 2009

(c) The Author(s) 2009. This article is published with open access at Springerlink.com

\begin{abstract}
The relationship between beaked whales and certain anthropogenic sounds remains poorly understood and of great interest. Although Cuvier's beaked whales (Ziphius cavirostris) are widely distributed, little is known of their behavior and population structure throughout much of their range. We conducted a series of five combined visual-acoustic marine mammal surveys from 2006 to 2008 in the southern San Nicolas Basin, a site of frequent naval activity off the southern California coast, west of San Clemente Island. The study area was defined by a $1,800 \mathrm{~km}^{2}$ array of 88 bottom-mounted hydrophones at depths up to $1,850 \mathrm{~m}$. The array was used to vector visual observers toward vocalizing marine mammal species. Thirty-seven groups of Cuvier's beaked whales were encountered during the study period. The overall encounter rate was one group for every $21.0 \mathrm{~h}$ of survey effort, and was as high as one group per $10.2 \mathrm{~h}$ of effort during the October 2007 survey. Whales were encountered in the deepest portion of the study area, at a mean bottom depth of $1,580 \mathrm{~m}$ (SD 138). The average group size was 3.8 individuals (SD 2.4), which was higher than has been
\end{abstract}

Communicated by S. Garthe.

E. A. Falcone $(\bowtie) \cdot$ G. S. Schorr · A. B. Douglas ·

J. Calambokidis

Cascadia Research Collective, 218 1/2 W. Fourth Avenue, Olympia, WA 98501, USA

e-mail: efalcone@cascadiaresearch.org

E. Henderson · M. F. McKenna · J. Hildebrand

Scripps Institution of Oceanography, 9500 Gilman Drive,

Mail Code 0210, La Jolla, CA 92093-0210, USA

D. Moretti

NAVSEA Division Newport, 1176 Howell Avenue,

Newport, RI 02841, USA reported from other studies of this species. Twenty-four groups were observed over multiple surfacings (median $=4$ surfacings, range 2-15). The mean encounter duration of extended sightings was $104 \mathrm{~min}$ (SD 98, range 12-466 $\mathrm{min}$ ) and the mean distance moved over the course of sightings was $1.66 \mathrm{~km}$ (SD 1.56, range 0.08-6.65 km). Temporal surfacing patterns during extended encounters were similar to dive behavior described from Cuvier's beaked whales carrying time-depth recording tags. Seventy-eight photographic identifications were made of 58 unique individuals, for an overall resighting rate of 0.26 . Whales were sighted on up to 4 days, with duration from first to last sighting spanning 2-79 days. For those whales sighted on subsequent days, the mean distance between subsequent sightings was $8.6 \mathrm{~km}$ (SD 7.9). Individuals resighted over 2-3 days were usually in association with previous group members. Approximately one-third of groups contained more than one adult male, and many of the repeated associations involved adult males. These observations suggest the basin west of San Clemente Island may be an important region for Cuvier's beaked whales, and also one which affords an unusual opportunity to collect detailed data on this species. Given its status as an active military range, it can also provide the ability to monitor the behavior of individuals in the presence of naval sonar, a critical step in the management of this and other beaked whale populations worldwide.

\section{Introduction}

The beaked whales (family Ziphiidae) are among the most poorly understood cetaceans. Interest in these species has increased considerably in recent years, as a number of beaked whale mortalities worldwide have been associated 
with high-intensity underwater sounds, such as certain types of naval sonar and seismic survey instruments (Simmonds and Lopez-Jurado 1991; Frantzis 1998; Balcomb and Claridge 2001; Jepson et al. 2003; Evans and Miller 2004; Fernández et al. 2005; Cox et al. 2006). Although Cuvier's beaked whales (Ziphius cavirostris) appear to be the most widely distributed ziphiids, with records from all but high polar waters, encounter rates are low throughout much of their range (Heyning 1989; Barlow et al. 2006; MacLeod and Mitchell 2006). Cuvier's beaked whales are typically sighted far from shore in water greater than $1,000 \mathrm{~m}$ deep, regularly conduct long dives with short intervening surfacing bouts, have a relatively inconspicuous surfacing profile, and may avoid boats-all characteristics that make them difficult to detect visually in anything less than ideal sighting conditions (e.g., Barlow 1999; Baird et al. 2006; Ferguson et al. 2006; Tyack et al. 2006; McSweeney et al. 2007). Consequently, there have been few long-term studies of Cuvier's beaked whale populations, and those undertaken have required many years of opportunistic or directed effort to accumulate substantial numbers of sightings. Although several recent studies have provided new insights into habitat preferences and group composition (Moulins et al. 2007), site fidelity and associative patterns (McSweeney et al. 2007), dive profiles (Baird et al. 2006), vocal behavior (Frantzis et al. 2002; Johnson et al. 2004; Zimmer et al. 2008), and movement patterns (Schorr et al. 2007), many basic aspects of their life history have not yet been adequately described, so any additional observations of these species are relevant. Here, we summarize sighting characteristics including group size and composition, distribution and habitat preference, and surfacing and movement patterns of Cuvier's beaked whales encountered in the southern San Nicolas Basin off the west side of San Clemente Island, during a series of five surveys from August 2006 to October 2008. As this is an area of frequent naval activity in southern California, we discuss the implications of these data in light of current knowledge of the species from other regions and their relevance to future management goals, both locally and abroad.

The presence of Cuvier's beaked whales in southern California was first described from stranded specimens in the mid-1950s (Mitchell 1968). Barlow and Forney (2007) broadly estimated the population of Cuvier's beaked whales off the US West Coast at 4,342 individuals $(\mathrm{CV}=0.58)$ with an overall density of 3.82 individuals per $1,000 \mathrm{~km}^{2}$ during ship-based line-transect surveys conducted from 1991 to 2005. Several studies have identified 'hotspots' or 'key areas' for beaked whales worldwide (Barlow et al. 2006; MacLeod and Mitchell 2006); however, no specific areas of unusual density have been previously reported off California. Site fidelity of individuals

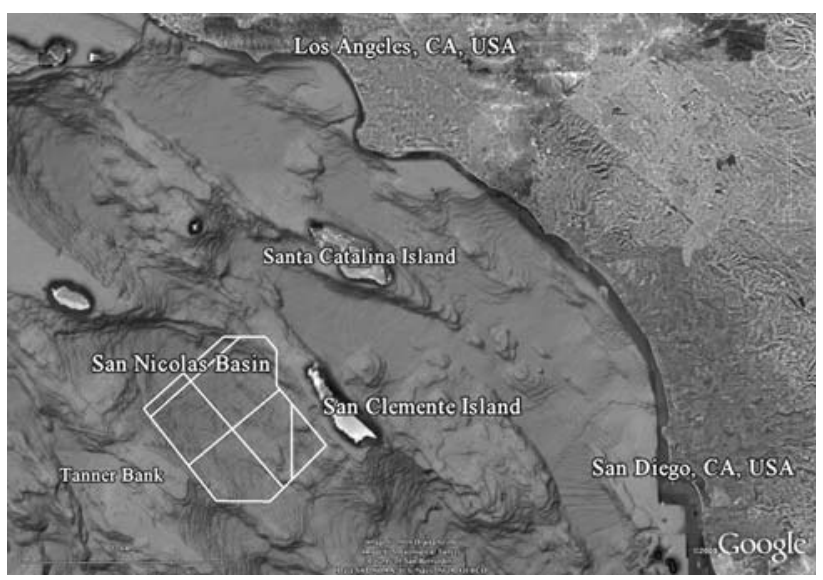

Fig. 1 Map of the Southern California Bight including San Clemente Island and location of SOAR hydrophone array (perimeter outlined in white) in the southern San Nicolas Basin. (Created using Google Earth and GPS Visualizer (Schneider 2003), topographical data courtesy 2009 Digital Globe, US geological survey, County of San Bernardino, SIO, NOAA, US Navy, NGA, and GEBCO)

over periods of months to years has been demonstrated in the Ligurian Sea and parts of Hawai'i through long-term photo-identification studies (Ballardini et al. 2005; McSweeney et al. 2007), but nothing is known regarding the population structure or site fidelity of Cuvier's beaked whales off California. The United States military's Southern California Offshore Complex (SOCAL) encompasses numerous naval training areas off the coast from Santa Barbara, California, USA to Baja California, Mexico. ${ }^{1}$ Given the apparent sensitivity of Cuvier's beaked whales to certain types of sonar, detailed knowledge of their presence and habitat use in southern California could contribute to the management of beaked whale populations in areas of frequent naval activity.

The United States Navy's Southern California AntiSubmarine Warfare Range (SOAR), which extends west into the San Nicolas Basin from San Clemente Island, is a focal training area within SOCAL (Fig. 1). SOAR consist of an array of 88 bottom-mounted hydrophones that are used for real-time, three-dimensional tracking of undersea vehicles ${ }^{1}$. These hydrophones monitor frequencies from 8 to $40 \mathrm{kHz}$ and are also useful in the detection of marine mammal species that vocalize within this bandwidth, such as Cuvier's beaked whales (Frantzis et al. 2002; Johnson et al. 2004; Zimmer et al. 2005). The SOAR array monitors an area approximately $1,800 \mathrm{~km}^{2}$ within the southern part of the San Nicolas Basin between San Clemente Island to the east and Tanner Bank to the west. The hydrophones are spaced throughout the basin 2-6 km apart at depths ranging from 758 to $1,858 \mathrm{~m}$, habitat suitable for Cuvier's beaked whales in other parts of the world, although the

\footnotetext{
${ }^{1}$ http://www.globalsecurity.org/military/facility/socal.htm.
} 
extent to which the species utilized the area was not known. Individual strandings have been historically reported on San Clemente Island and nearby Santa Catalina and San Nicolas Islands (Mitchell 1968), but no confirmed mass strandings of beaked whales have been reported in any part of southern California.

\section{Materials and methods}

We began a cooperative visual-acoustic study of marine mammals at SOAR in August 2006. Acoustic observers remotely monitored the hydrophone array on shore using the Marine Mammal Monitoring on Navy Ranges (M3R) passive acoustic real-time tools (Moretti et al. 2006). The M3R system was initially developed for detection and localization of marine mammals at the Atlantic Undersea Test and Evaluation Center (AUTEC) in the Bahamas, where it has been successfully used to localize groups of Blainville's beaked whales (Mesoplodon densirostris) (Moretti et al. 2006), and more recently to track movement patterns, estimate vocal rates, and even derive density estimates for the species within the array (DiMarzio et al. 2008; Ward et al. 2008; Marques et al. 2009). The initial goal of these surveys was to adapt the existing M3R system for use at SOAR, which presented technical challenges due to differences in the design and layout of the array and the much higher diversity and abundance of vocal species in the region. Based on the remote monitoring, trained surface observers were vectored to areas where vocalizing species were detected so that animals could be accurately identified and localized. Although boats might be directed toward any vocalizing species detected within the array, priority was given to vocalizations in the appropriate frequency range for beaked whales. When marine mammals were visually detected (with or without acoustic direction), the estimated group size, group envelope (approximate area encompassing the group in $\mathrm{m}^{2}$ ), and behavioral state were recorded, and photos were taken both for species verification and photo-identification of individual group members.
The time, latitude, and longitude were recorded at the initial position of all marine mammal sightings. When beaked whales were encountered an attempt was made to maintain contact with the group as long as possible to document dive intervals and movements. During extended beaked whale sightings, the exact time and position of the terminal dive of each surfacing bout was recorded.

Five surveys ranging in length from 5 to 10 days were conducted from 2006 to 2008 (Table 1). All surveys involved the use of one or two rigid-hull inflatable boats (5.3-5.9 $\mathrm{m}$ in length), and later surveys included the $38.1 \mathrm{~m} \mathrm{R} / \mathrm{V}$ Robert Gordon Sproul as an additional sighting platform (Scripps Institution of Oceanography). In August 2006 and April 2007 boats were launched daily from Wilson Cove on the northeastern corner of San Clemente Island and then transited approximately $22 \mathrm{~km}$ to reach the northeastern boundary of the study area. Transit time, prevailing winds, and occasional range restrictions constrained much of the survey to the northeastern part of the array during these field efforts. Subsequent surveys (October 2007, August and October 2008) were based from the Sproul, which launched the smaller boats daily, allowing them to remain in or near the study area throughout the survey, and to focus effort on the southern and western portions of the array that had not been adequately covered in previous surveys due to logistics and weather (Fig. 2). There were two or three experienced visual observers on effort aboard the Sproul during daylight hours, thus providing a third, much higher observation platform (7 $\mathrm{m}$ above waterline) from which sighting data were collected. Due to observer height, sightings from the Sproul were often at a distance from the ship. In these cases, sighting position was calculated from the ship's position and heading, angle to the sighting, and reticle reading from $7 \times 50$ binoculars. The time and position of all weather changes were recorded by each platform while on effort. During "excellent" and "good" sighting conditions (defined as Beaufort sea state less than four with no significant impairment in visibility due to atmospheric conditions or swell height), survey vessels worked

Table 1 Survey effort and sightings of Cuvier's beaked whales west of San Clemente Island, 2006-2008

\begin{tabular}{|c|c|c|c|c|c|c|c|}
\hline Survey dates & Vessels & $\begin{array}{l}\text { Vessel } \\
\text { days }\end{array}$ & $\begin{array}{l}\text { Total } \\
\text { survey } \\
\text { hours }\end{array}$ & $\begin{array}{l}\% \text { Total hours in } \\
\text { excellent or good } \\
\text { conditions }\end{array}$ & $\begin{array}{l}\text { Z.c. } \\
\text { sightings }\end{array}$ & $\begin{array}{l}\text { Sighting rate } \\
\text { (hrs/sighting) }\end{array}$ & $\begin{array}{l}\text { Average } \\
\text { group size }\end{array}$ \\
\hline 14-20 August 2006 & $5.3 \mathrm{~m}$ RHIB, $5.9 \mathrm{~m}$ RHIB & 13 & 123.4 & 0.59 & 1 & 123.4 & 2.0 \\
\hline 13-22 April 2007 & $5.3 \mathrm{~m}$ RHIB, $5.9 \mathrm{~m}$ RHIB & 12 & 88.5 & 0.47 & 0 & & \\
\hline 22-26 October 2007 & Two $5.3 \mathrm{~m}$ RHIBS, $38.1 \mathrm{~m} \mathrm{R} / \mathrm{V}$ Sproul & 15 & 143.4 & 0.70 & 14 & 10.2 & 4.4 \\
\hline 2-10 August 2008 & Two $5.3 \mathrm{~m}$ RHIBS, $38.1 \mathrm{~m} \mathrm{R} / \mathrm{V}$ Sproul & 22 & 228.5 & 0.56 & 13 & 17.6 & 4.0 \\
\hline 17-27 October 2008 & $5.3 \mathrm{~m} \mathrm{RHIB}, 38.1 \mathrm{~m} \mathrm{R} / \mathrm{V}$ Sproul & 20 & 192 & 0.46 & 9 & 21.3 & 2.6 \\
\hline
\end{tabular}

Conditions were considered "Excellent" or "Good" at a Beaufort sea state less than four, with no significant impairment in visibility due to atmospheric conditions, precipitation, or swell height 


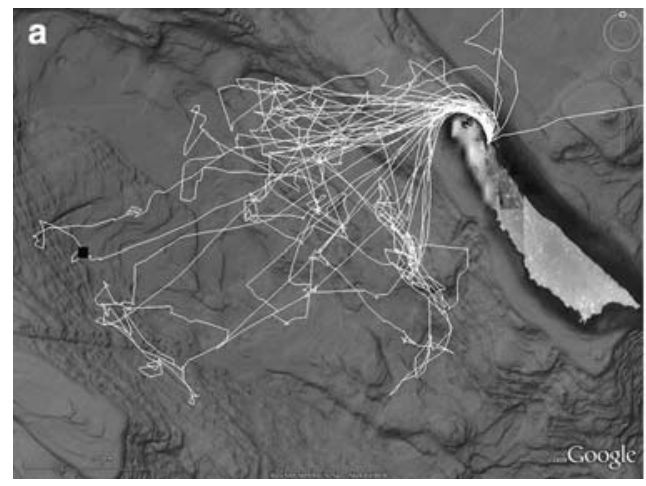

Fig. 2 Survey effort (white lines) and Cuvier's beaked whale sightings (black squares) on the SOAR hydrophone array 20062008. a Represents surveys in August 2006 and April 2007. b Represents surveys in October 2007, August 2008, and October

separately to localize as many different groups as possible; as conditions declined vessels coordinated search patterns around single localizations.

All effort, sighting, and photo-identification data were entered into an Access sighting database (Microsoft, Redmond, WA, USA). Sproul sighting positions and straightline distances between all positions were calculated using the Bearing, NewPosLat, NewPosLong, and Posdist spherical geometry functions in Excel (Microsoft, Redmond, WA, USA) (Laake 2001). The depth and slope at all initial beaked whale sighting positions were extracted by overlaying point location data on an $85 \mathrm{~m}$ resolution bathymetric raster surface in ArcGIS Version 9.2 (ESRI, Redlands, California, USA). Depth (in meters) and slope values (in degrees) were transferred to point locations using the 'intersect point tool' in Hawth's analysis tools (Beyer 2004). The depths at all hydrophone positions were also extracted for comparison against sighting position depths.

All photos of adequate quality from each Cuvier's beaked whale sighting were sorted to individual, and the best photo of the left and right sides of each whale in a sighting were rated for quality and individual distinctiveness following criteria employed by McSweeney et al. (2007). All best-of-sighting identification photographs were compared between sightings to identify resightings of individuals over time. The single best left and right side photographs of each whale from all sightings were used to create a catalog of unique individuals identified during the study period. This catalog was then filtered by image quality, individual distinctiveness, and side of the body photographed to ascertain a conservative minimum estimate of the number of unique whales identified.

Whales were assigned to a probable sex and age class using all available photos of the head and body of each individual across sightings. Adult male Cuvier's beaked

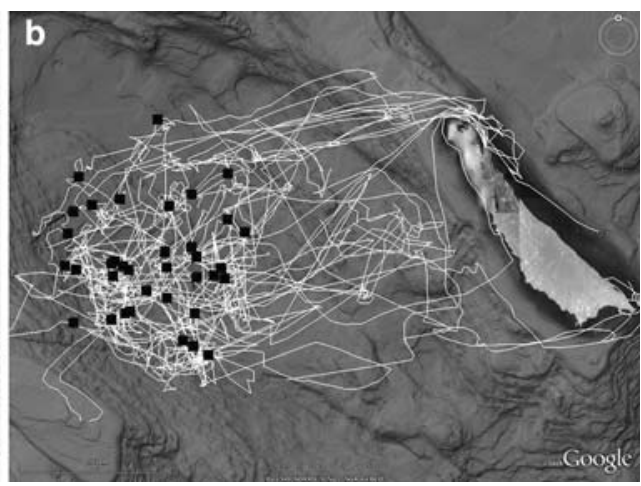

2008. (Created using Google Earth and GPS Visualizer (Schneider 2003), topographical data courtesy SIO, NOAA, US Navy, NGA, and GEBCO)

whales can be identified by extensive linear scarring on the body believed to result from interactions with other males, and by the presence of two small, erupted teeth visible at the tip of the rostrum (Heyning 1989). The distinction between other sex and age classes can be more subtle and may vary between regions (McSweeney et al. 2007; Moulins et al. 2007; M. Rossi, personnel communication 2009). We found that in the field, with the exception of small calves, variation in relative body size was often not obvious, but that size differences were more discernable in photographs of closely associated individuals. We also found that pigmentation patterns, and in some cases scarring, were obscured by a layer of dark brown diatoms covering the entire body except the very tip of the rostrum. In Hawai'i, adult females can be distinguished from larger sub-adults of either sex, which may otherwise appear similar, by the accumulation of white oval scars (resulting from cookie-cutter shark bites) on the body (McSweeney et al. 2007). We assessed the minimum number of oval scars on each side of all photographed whales to determine if this characteristic could also be used for assigning whales to age classes in this study, and found that many whales had no visible oval scars one side of the body (including adults confirmed by other characteristics), and that these scars were far less extensive on those whales which did bear them (mean $=1.8$ oval scars per side, range 1-11) than has been described in Hawai'i ( $>200$ scars per side on confirmed adults, McSweeney et al. 2007). It was thus determined that this feature cannot be used to differentiate adult females from larger sub-adults in our study area, so adult females were identified by the following criteria: large body size (confirmed by photographs of the whale with other group members in close proximity), the presence of light pigmentation on the rostrum, lack of erupted teeth, and, if present, the close association of a much smaller animal presumed to be a calf. 
Large, lightly scarred whales with no clear photographs of the rostrum were considered adults of unknown sex. Whales with minimal linear scarring that were small relative other group members in photos, but not closely associated with an adult female, were considered sub-adults of unknown sex. Minimally scarred whales whose body size could not be assessed and who lacked clear shots of the head were classified as unknown sex and age class. An analysis of group composition was conducted using groups in which all individuals were identified and assigned a sex and age class.

\section{Results}

Thirty-seven groups of Cuvier's beaked whales were sighted during the study (Table 1), with all but one sighting occurring in October 2007 or later. The overall sighting rate for Cuvier's beaked whales during the study was one sighting for every $21.0 \mathrm{~h}$ of effort. The highest sighting rate was observed during the October 2007 survey (one sighting for every $10.2 \mathrm{~h}$ of survey effort in all conditions, one sighting per $7.2 \mathrm{~h}$ of effort in excellent or good survey conditions). The estimated number of whales per sighting ranged from 1 to 10 , and 14 groups contained five or more individuals, although two of these large groups consisted of multiple sub-groups of 2-3 whales that were surfacing asynchronously within $1 \mathrm{~km}$ of each other. As sub-groups in these small aggregations sometimes surfaced within the average distance moved by groups between surfacings, they could not be easily tracked individually in the field. Subsequently they were treated as a single sighting in the data, with best overall group size estimated from detailed surfacing location, dive interval, and photo-identification data. The mean group size was 3.8 individuals (SD 2.4, median $=3$ ). Although the mean group sizes varied from 4.4 during the October 2007 survey to 4.0 in August 2008 and 2.6 in October 2008, these differences were not significant (Single-factor ANOVA, $F[2,33]=1.78$, $P=0.18)$.

Cuvier's beaked whales were sighted only in the western part of the study area, which corresponded to the deepest part of the basin within the SOAR array (Fig. 2b). All sightings occurred within an area roughly $700 \mathrm{~km}^{2}$, and the mean pair-wise distance between all groups sighted during the study was $12.2 \mathrm{~km}$ ( $\mathrm{SD}=5.9, n=666$ combinations). The mean daily pair-wise distance between unique groups was $8.6 \mathrm{~km}$ for those days in which three or more unique groups were sighted ( $n=6$ days). Bottom depth at initial sighting positions ranged from 1,045 to $1,741 \mathrm{~m}$ (mean $=1,580 \mathrm{~m}, \quad \mathrm{SD}=138, n=37$ ), and sightings occurred in water significantly deeper than the mean bottom depth of array hydrophones of 1,376 m $(\mathrm{SD}=240 \mathrm{~m})$
(Two Sample $t$-Test of depth at sighting positions vs. depth at hydrophone positions, $P<0.01)$. The median slope at initial sighting positions was one degree (range $=0-17$ ). Because most sightings occurred over nearly flat bathymetry, aspect was highly variable and not considered further.

Twenty-six groups were observed over multiple surfacing series, with all but one extended encounter in excellent or good sighting conditions when animals could be relocated after dives with a reasonable level of confidence by both the RHIBs and the Sproul. The total sighting duration for 26 groups observed on more than one surfacing bout ranged from 12 to 466 min (median $=68$, mean $=129, \mathrm{SD}=112$ ), although whales were visible at the surface only a small portion of that time. Two of the 26 extended sightings consisted of several loosely associated subgroups which surfaced asynchronously within a limited area. Given the difficulty of reliably tracking specific subgroups across dives, these two sightings were excluded from detailed analyses of surfacing bouts and associated intervals. The number of surfacing bouts observed during a sighting ranged from 1 to 15 , and for the 24 groups reliably observed at the surface more than once, the modal number of bouts observed was 4 (mean $=5.1, \mathrm{SD}=3.5$ ). The mean straight-line distance between subsequent surfacing bouts was $0.80 \mathrm{~km}$ (range $0.09-2.23, \mathrm{SD}=0.50, n=85$ ) and the mean straight-line distance between the first and last observed surfacing bout was $1.66 \mathrm{~km}$ (range 0.08 6.65 , SD $1.56, n=24$ ), resulting in a mean minimum rate of straight-line movement of $1.38 \mathrm{~km} / \mathrm{h}$ (SD 0.90 ) over the course of a sighting.

The duration between the terminal dives of subsequent surfacing bouts (referred to as "surfacing interval" or SI) was calculated as an estimate of total dive duration, since the exact time and location of the initial surfacings in a bout could not always be recorded when groups surfaced at a distance from the vessel, and time at the surface was generally short (approximately $2 \mathrm{~min}$ ) relative to time at depth. SI ranged from 9 to 85 min with a median SI of $24 \min (n=85$ SI from 24 groups totaling an estimated 83 whales). SI of 20-30 min were the most frequently observed (57\% of all SI) and the overall ratio of short SI ( $<50 \mathrm{~min}$ ) to long SI (>50 min) was 5.3 to 1 , although groups were more likely to be lost during long SI so these may be underrepresented in the sample. Most long SI were preceded by four to six short SI, with the exception to this being groups which had a long SI shortly following their initial sighting.

A total of 2,495 identification photographs were taken during 24 of the 37 Cuvier's beaked whale sightings. Of the estimated 109 whales sighted and approached for photoidentification, $78(72 \%)$ had sufficient quality photographs to be compared between sightings. Reconciliation of photographs of these 78 whales resulted in 58 different 
individuals, for an overall resighting rate of 0.26 during the study using photos of all qualities and distinctiveness. A conservative minimum catalog of 43 individuals was restricted to only those whales with high-quality photos of both the left and right sides $(n=22)$, high-quality right sides only $(n=18)$, and high-quality left sides only, but with a distinctive dorsal fin shape or notches in the back that could reliably be identified from the right side as well $(n=3)$. Of the 58 individuals in the unrestricted catalog, 41 were adults $(71 \%), 3$ were sub-adults $(5 \%), 5$ were calves $(9 \%)$, and $9(15 \%)$ were unknown age. Of the 41 adults, 19 were female (46\%), 16 were male (39\%), and $6(15 \%)$ were of unknown sex.

Most photographed groups contained individuals of multiple sex and age classes. At least 10 groups contained more than one identified adult male (range 2-5 males per group), but of nine fully identified groups of two or more whales, none consisted of only adult males. No calves were sighted during the first three surveys, but five different calves were sighted in six groups during surveys in 2008. No group contained more than one calf. The mean size of groups containing a calf was 4.7 whales $(\mathrm{SD}=2.6, n=6)$ versus 3.7 whales ( $\mathrm{SD}=2.7, n=22$ ) for those groups with no calves present, however, this difference was not significant (Two Sample $t$-test, $P=0.45$ ).

Fifteen whales were identified on more than 1 day for a total of 20 resightings, and in all but one case whales were resighted in association with group members from a previous sighting. Whales were resighted on up to three separate days, with the majority of resightings within 3 days of the initial sighting; however, one adult female was sighted on two subsequent days in August 2008 and then sighted again 78 days later (with different associates) on two subsequent days in October 2008. In her first October sighting this whale was $9.8 \mathrm{~km}$ from her previous sighting position in August. The mean horizontal distance moved between all individual resightings was $8.6 \mathrm{~km}$ (range $=1.5-24.9$, $\mathrm{SD}=7.9, n=7$ unique movements, as duplicate movements by repeatedly associated individuals were removed).

\section{Discussion and conclusions}

The overall sighting rate of Cuvier's beaked whales in the southern San Nicolas Basin during combined visualacoustic surveys (one sighting per 21.0 effort hours overall, as high as one sighting every $10.2 \mathrm{~h}$ during the October 2007 survey) is high relative to many other published studies of this species. Mean group sizes observed during this study were also higher than have been reported from other sources (Table 2). Although the sighting rate was influenced by the ability to localize groups with the M3R system, particularly during later surveys as localizations became more reliable, groups were also encountered independent of acoustic direction throughout the study. Given the non-standardized, non-random nature of survey effort, and the evolving role of acoustic localizations, it is difficult to compare these detection rates to other studies. However, Cuvier's beaked whales were sighted only once every $51 \mathrm{~h}$ of dedicated survey effort for beaked whales in a long-term study in Hawai'i (McSweeney et al. 2007), suggesting that with the M3R system and larger average group sizes, this region may offer more frequent opportunities to observe this species than many other regions have.

Several results suggest that there is, at least at times, a high density of animals in the southern San Nicolas Basin. Unfortunately, the only regional density measures to which these observations can be compared are derived from standardized, large-scale estimates from line-transect surveys (Barlow and Forney 2007), which correlate poorly with observations resulting from targeted effort during this study. While several line-transect surveys passed through the southern San Nicolas Basin in good sighting conditions, an unusual abundance of Cuvier's beaked whales was not reported. From 23 to 26 October 2007 we identified a minimum of 21 unique individuals within an area approximately $420 \mathrm{~km}^{2}$. If we assume that animals identified during that 4-day period remained in the area, as the limited movements of resighted individuals suggest is likely, this would correspond to an average density of 50
Table 2 Mean group size of Cuvier's beaked whales from other published sources in comparison to those observed in the Southern San Nicolas Basin 2006-2008

\begin{tabular}{llllc}
\hline Region & Source & $\begin{array}{l}\text { Mean group } \\
\text { size }\end{array}$ & Range & Groups \\
\hline Costa Rica EEZ, Central America & May-Collado et al. (2005) & 2.6 & NR & 14 \\
Various worldwide & MacLeod and D'Amico (2006) & 2.3 & $1-15$ & 189 \\
Northwestern Mediterranean Sea & Moulins et al. (2007) & 2.3 & $1-11$ & 247 \\
Great Abaco Island, Bahamas & Claridge (2006) & 2.44 & $1-5$ & 18 \\
Southern Gulf of California, Mexico & Barlow et al. (1997) & 2.5 & $1-5$ & 21 \\
Hawaii, Big Island & McSweeney et al. (2007) & 2.57 & $1-5$ & 28 \\
California Current System & Barlow and Forney (2007) & 2.6 & NR & 17 \\
San Nicolas Basin, California & This study & 3.76 & $1-10$ & 37 \\
\hline
\end{tabular}


individuals per $1,000 \mathrm{~km}^{2}$ in the western portion of the study area during the period. If we included all whales identified within the limited area during that time, irrespective of photo quality $(n=28)$, and accounted for individuals that were not identified in each sighting ( $n=21)$ and controlled for the observed recapture rate during that time $(0.28)$, the actual minimum number of whales in the area was likely closer to 34 , yielding a density of 81 individuals per $1,000 \mathrm{~km}^{2}$. Even our more conservative estimate is higher than the density estimated for the southern Gulf of California "hotspot" for Cuvier's beaked whales of 38 animals per $1,000 \mathrm{~km}^{2}$ (Barlow et al. 2006). This suggests that the region may represent important habitat for Cuvier's beaked whales. As the M3R system is further refined, passive acoustic monitoring may provide an alternative and more standardized means of estimating density within this study area than visual surveys can provide, as has been done for Blainville's beaked whales using data from the AUTEC Range (Marques et al. 2009). Additional surveys in adjacent areas, such as the northern San Nicolas Basin and other nearby locations with similar bathymetric profiles could help define the spatial limits of this apparent aggregation beyond the reach of the hydrophone array.

Given the limited seasonal sampling and duration of this study, it is not clear whether the number of animals observed in the latter three surveys is typical. We believe the lack of sightings in the first two surveys is at least partly explained by bias in effort toward unfavorable habitat (Fig. 2a), poor sighting conditions (Table 1), and lack of accurate acoustic localizations during the preliminary stages of M3R system development at the SOAR array. It remains possible, however, that the abundance of Cuvier's beaked whales in the Southern California Bight may fluctuate seasonally or annually in response to oceanographic factors. Studies have identified sources of both seasonal and multi-annual variation in deep-water productivity due to periodic flushing of stagnant bottom water from basins within the Southern California Bight, including the San Nicolas Basin (Berelson 1991). Both the increased flow rates at depth and the influx of oxygenated water could produce substantial variation in prey availability for beaked whales associated with these cycles, which would presumably affect the distribution and density of beaked whales in the region as well. Expanded survey coverage during additional seasons and over a period of years will be required to better define seasonal and annual variation in Cuvier's beaked whale occurrence and identify any longterm oceanographic patterns that may correlate with changes in local abundance.

Bathymetric features such as depth and slope have been significantly correlated with the occurrence of Cuvier's beaked whales in other regions where the species has been studied (Cañadas et al. 2002; Moulins et al. 2007), although Ferguson et al. (2006) suggest that this species may occur over a broader range of habitat than more localized studies suggest. The bottom depth of sightings from all other study areas, however, has consistently averaged over $1,000 \mathrm{~m}$ (Cañadas et al. 2002; Claridge 2006; Ferguson et al. 2006; McSweeney et al. 2007; Moulins et al. 2007), which was also true of sightings reported here. While the degree to which slope has correlated with sightings from other areas has varied, higher densities of Cuvier's beaked whales have been reported in areas corresponding to the lower slope of canyons or offshore continental shelf edge in some regions (Ferguson et al. 2006; Moulins et al. 2007). MacLeod and Zuur (2005) correlated the occurrence of Blainville's beaked whales with habitat likely to accumulate prey given predominant deep-water currents in the study area. Deep circulation in the Southern California Bight is complex, variable, and not well understood; however, predominant deep water flow into basins is from the southeast, driven in part by the California Undercurrent (Lynn and Simpson, 1990). Although this current runs at much shallower depths (150-300 m) than Cuvier's beaked whales appear to forage ( $>1,000$ m, Aguilar Soto et al. 2006; Baird et al. 2006), this northwesterly flow could affect productivity or prey distribution where it interacts with the eastern slope of Tanner Bank and the sill extending north from it toward San Nicolas Island, which is near where the majority of sightings occurred (Fig. 2b). Without more detailed studies of deep water circulation within the region, particularly coincident with beaked whale observations, it may prove difficult to understand the effect of oceanographic factors on their distribution.

Although limited, results of this study have provided several insights into Cuvier's beaked whale behavior and sociality. Those groups tracked over multiple dive cycles demonstrated a surfacing pattern that is consistent with what has been reported from previous dive interval studies and from Cuvier's beaked whales carrying time-depth recording tags in other regions (Barlow et al. 1997; Baird et al. 2006; Tyack et al. 2006), further defining normal surfacing behavior in this species. The social organization of Cuvier's beaked whales has not been well described; however, the prevalence of groups containing multiple males, the repeated associations between some individual adult males over several days, and the overall group sizes of Cuvier's beaked whales at San Clemente are similar to observations of northern bottlenose whales (Hyperoodon ampullatus) in the Gully off Nova Scotia (Gowans et al. 2001). A long-term, detailed study of the social organization of these latter beaked whales demonstrated the strongest social affiliations exist within the classes of mature and sub-adult males, with some pairs forming bonds that may persist for years, and that females and immature 
whales have a more fluid social network without preferred partners of any sex or age class (Gowans et al. 2001). Our results suggest a similar social structure may exist within Cuvier's beaked whale populations. McSweeney et al. (2007) also noted two males were present in 5 of 28 Cuvier's beaked whale sightings in Hawai' $i$; implying that, at a minimum, the social structure of Cuvier's beaked whales differs from that of Blainville's beaked whales. Although group sizes for the two species are similar (MacLeod and D'Amico 2006), multiple males are seldom observed in groups of Blainville's beaked whales, for which female defense polygyny has been suggested as a likely mating strategy (Claridge 2006).

The relationship between beaked whale mortality and anthropogenic sound is yet to be fully explained, and remains a critical element to managing impacts on these species. Evans and Miller (2004), Cox et al. (2006), and Rommel et al. (2006) all explored potential mechanisms by which anthropogenic sound may result in strandings given present knowledge of beaked whale behavior and physiology, and noted the possibility of an "acoustically induced behavioral change" in which whales alter their normal dive cycle in response to an acoustic signal. Zimmer and Tyack (2007) modeled the formation of nitrogen gas bubbles in beaked whale tissues under various dive cycles, and found that an extended series of dives to depths between 22 and $72 \mathrm{~m}$, a pattern not observed in freeranging tagged whales, could lead to bubble formation and decompression-like sickness in beaked whales. If the primary cause of beaked whale mortality in the presence of certain anthropogenic sounds lies in a behavioral response rather than a direct physiological effect, then habituation to those sounds might explain how substantial numbers of these animals could exist in or near areas of frequent activity, such as off the west coast of San Clemente Island. This is particularly true if a degree of site fidelity, similar to that which has been observed for beaked whales in Hawai'i (McSweeney et al. 2007), exists for this population, and hence whales might regularly be exposed to sound throughout their lives. If naïve individuals are more likely to react adversely to sound, it might explain the prevalence of juvenile and immature animals in previous sound-related mass strandings (MacLeod and D'Amico 2006). Unfortunately, available data on the age class composition of populations and growth rates in Cuvier's beaked whales are insufficient to rule out other sources of these biases in prior strandings. Continued photo-identification, and also satellite tagging, of this population will help to define population size and residency, and can potentially address longer term patterns of sound exposure should sonar use data become available.

As the waters west of San Clemente Island are an area of frequent naval activity, the potential to encounter numbers of Cuvier's beaked whales there at any time is of interest, given the sensitivity of this species to certain types of sound in other parts of its range. It should be specifically noted that neither visual nor acoustic marine mammal observations were permitted on the array during most active naval operations, so observations presented here correspond to times with little or no use of underwater sound sources. Controlled exposure experiments have been identified as a critical next step to understanding, and ultimately mitigating, the impacts of anthropogenic sound on beaked whales (Evans and Miller 2004; Cox et al. 2006). Encounters with these whales within the SOAR array can provide opportunities for direct observations in the presence of, and potentially with the controlled use of, naval sound sources such as the $53 \mathrm{C}$ mid-frequency active sonar implicated in some mass strandings. A combination of passive acoustic monitoring with the range sensors, satellite and acoustic tagging, and surface observations could be used to study the movements and vocal behavior of animals before, during, and after active sonar operations routinely conducted in the region.

A better understanding of factors such as the distribution and density of animals over time, immigration and emigration patterns, calving and growth rates, predatorprey relationships, and responses to environmental change is essential to the management of this and other beaked whale populations worldwide. The relatively accessible waters west of San Clemente Island, with the potential for acoustic direction using the M3R system, represents an ideal location to collect ecological, behavioral, and acoustic data on Cuvier's beaked whales in both the presence and absence of naval sound sources, and a long-term study of this population would be highly valuable.

Acknowledgments Data were collected under NMFS permit number 540-1811. Work was supported by funding from the US Navy N45 program. We wish to acknowledge Tarry Rago, Ron Morissey, Nancy DiMarzio, Susan Jarvis, Erin Oleson, Greg Campbell and Melissa Soldevilla for their role in remote acoustic monitoring. We wish to thank Captain Richard Vullo and the crew of the Sproul. We gratefully acknowledge the assistance of Jennifer Quan, Sara Blakeslee, Judd McGhee, Daniel Webster, Jeff Jacobsen, Bethany Diehl, Ilana Berry, Lillian Luce, Daniel Laggner, Greg Campbell, and Dave Weller during field data collection. Dean Yamashita, D. J. Pascua, Heidi Nevitt and numerous other personnel on San Clemente Island and at the Range Operations Center on North Island, San Diego provided essential logistical and technical support during surveys. Megan Ferguson and Damon Holzer assisted with GIS analyses. Thanks are due to Robin Baird, Gretchen Steiger, Phil Clapham, and three anonymous reviewers for their comments on early versions of this text.

Open Access This article is distributed under the terms of the Creative Commons Attribution Noncommercial License which permits any noncommercial use, distribution, and reproduction in any medium, provided the original author(s) and source are credited. 


\section{References}

Aguilar Soto N, Johnson M, Madsen PT, Tyack PL, Bocconcelli A, Borsani JF (2006) Does intense ship noise disrupt foraging in deep-diving Cuvier's beaked whales (Ziphius cavirostris)? Mar Mamm Sci 22(3):690-699

Barlow J, Forney K (2007) Abundance and population density of cetaceans in the California current ecosystem. Fish Bull 105:509-526

Baird RW, Webster DL, McSweeney DJ, Ligon AD, Schorr GS, Barlow J (2006) Diving behaviour of Cuvier's (Ziphius cavirostris) and Blainville's (Mesoplodon densirostris) beaked whales in Hawai'i. Can J Zool 84:1120-1128

Balcomb KC, Claridge DE (2001) A mass stranding of cetaceans caused by naval sonar in the Bahamas. Bahamas J Sci 5:1-12

Ballardini M, Pusser T, Nani B (2005) Photo-identification of Cuvier's beaked whales (Ziphius cavirostris) in the northern Ligurian Sea. Proceedings of the 14th annual conference of the European cetacean society, La Rochelle, 4-7 April 2005

Barlow J (1999) Trackline detection probability for long-diving whales. In: Garner GW, Amstrup SC, Laake JL, Manly BFJ, McDonald LL, Robertson DG (eds) Marine mammal survey and assessment methods. A. A. Balkema Publishers, The Netherlands, pp 209-221

Barlow J, Forney K, Von Saunder A, Urban-Ramirez J (1997) A report of cetacean acoustic detection and dive interval studies (CADDIS) conducted in the southern Gulf of California, 1995. NOAA-TM-NMFS-SWFSC-250

Barlow J, Ferguson MC, Perrin WF, Ballance L, Gerrodette T, Joyce G, MacLeod CD, Mullin K, Palka DL, Waring G (2006) Abundance and densities of beaked and bottlenose whales (family Ziphiidae). J Cetacean Res Manag 7:263-270

Berelson WM (1991) The flushing of two deep-sea basins, southern California borderland. Limnol Oceanogr 36(6):1150-1166

Beyer HL (2004) Hawth's analysis tools for ArcGIS ${ }^{\circledR}$. Version 3.21 [computer program]. Available from http://www.spatialecology. $\mathrm{com} / \mathrm{htools}$

Cañadas AM, Sagarminaga R, García-Tiscar S (2002) Cetacean distribution related with depth and slope in the Mediterranean waters off southern Spain. Deep Sea Res I 49:2053-2073

Claridge DE (2006) Fine-scale distribution and habitat selection of beaked whales. M.Sc. thesis, University of Aberdeen, Scotland, $119 \mathrm{pp}$

Cox TM, Ragen TJ, Read AJ, Vos E, Baird RW, Balcomb K, Barlow J, Caldwell J, Cranford T, Crum L, D'Amico A, D'spain G, Fernández A, Finneran J, Gentry R, Gerth W, Gulland F, Hildebrand J, Houser D, Hullar T, Jepson PD, Ketten D, MacLeod CD, Miller P, Moore S, Mountain D, Palka D, Ponganis P, Rommel S, Rowles T, Taylor B, Tyack P, Wartzok D, Gisiner R, Mead J, Benner L (2006) Understanding the impacts of anthropogenic sound on beaked whales. J Cetacean Res Manag 7:177-187

DiMarzio N, Moretti D, Ward J, Morrissey R, Jarvis S, Izzi AM, Johnson M, Tyack P, Hansen A (2008) Passive acoustic measurement of dive vocal behavior and group size of Blainville's beaked whale (Mesoplodon Densirostris) in the Tongue of the Ocean (TOTO). Can Acoust 36(1):166-173

Evans PGH, Miller LA (eds) (2004) Active sonar and cetaceans. Proceedings of workshop held at the ECS 17th annual conference, Las Palmas, 8th March 2003. European Cetacean Society, Kiel, 84 pp

Ferguson MC, Barlow J, Reilly SB, Gerrodette T (2006) Predicting Cuvier's (Ziphius cavirostris) and Mesoplodon beaked whale population density from habitat characteristics in the eastern tropical Pacific Ocean. J Cetacean Res Manag 7:287-299
Fernández A, Edwards JF, Rodriguez F, Espinosa Delos Monteros A, Herraez P, Castro P, Jaber JR, Martin V, Arbelo M (2005) "Gas and fat embolic syndrome" involving a mass stranding of beaked whales (Family Ziphiidae) exposed to anthropogenic sonar signals. Vet Pathol 42:446-457

Frantzis A (1998) Does acoustic testing strand whales? Nature 392:29

Frantzis A, Goold JC, Skarsoulis EK, Taroudakis MI, Kandia V (2002) Clicks from Cuvier's beaked whales, Ziphius cavirostris (L.). J Acoust Soc Am 112:34-37

Gowans S, Whitehead H, Hooker SK (2001) Social organization in northern bottlenose whales, Hyperoodon ampullatus: not driven by deep-water foraging? Anim Behav 62:369-377

Heyning JE (1989) Cuvier's beaked whale Ziphius cavirostris G. Cuvier, 1823. In: Ridgway SH, Harrison R (eds) Handbook of marine mammals. Volume 4. River dolphins and the larger toothed whales. Academic Press, London, pp 289-308

Jepson PD, Arbelo M, Deaville R, Patterson IAP, Castro P, Baker JR, Degollada E, Ross HM, Herraez P, Pocknell AM, Rodriguez F, Howie FE, Espinosa A, Reid RJ, Jaber JR, Martin V, Cunningham AA, Fernández A (2003) Gas-bubble lesions in stranded cetaceans. Nature 425:575-576

Johnson M, Madsen PT, Zimmer WMX, Aguilar De Soto N, Tyack PL (2004) Beaked whales echolocate on prey. Proc Roy Soc Lond Ser B 271(S6):383-386

Laake JL (2001) Excel geometry functions. http://nmml.afsc.noaa. gov/Software/ExcelGeoFunctions/excelgeofunc.htm. Accessed 26 May 2009

Lynn RJ, Simpson JJ (1990) The flow of the undercurrent over the continental borderland off Southern California. J Geophys Res 95(C8):12955-13008

MacLeod CD, Mitchell G (2006) Key areas for beaked whales worldwide. J Cetacean Res Manag 7:309-322

MacLeod CD, D'amico A (2006) A review of beaked whale behavior and ecology in relation to assessing and mitigating impacts of anthropogenic noise. J Cetacean Res Manag 7:211-221

Marques TA, Thomas L, Ward J, DiMarzio N, Tyack PL (2009) Estimating cetacean population density using fixed passive acoustics sensors: an example with beaked whales. J Acoust Soc Am 125(4):1982-1994

May-Collado L, Gerrodette T, Calambokidis J, Rasmussen K, Sereg I (2005) Patterns of cetacean sighting distribution in the Pacific exclusive economic zone of Costa Rica based on data collected from 1979-2001. Int J Trop Biol 53:249-263

MacLeod CD, Zuur AF (2005) Habitat utilization by Blainville's beaked whales off Great Abaco, Northern Bahamas, in relation to seabed topography. Mar Biol 174:1-11

McSweeney D, Baird RW, Mahaffy SD (2007) Site fidelity, associations, and movements of Cuvier's (Ziphius cavirostris) and Blainville's (Mesoplodon densirostris) beaked whales off the island of Hawai'i. Mar Mamm Sci 23:666-687

Mitchell E (1968) Northeast Pacific stranding distribution and seasonality of Cuvier's beaked whale, Ziphius cavirostris. Can J Zool 46:265-279

Moretti D, Morissey R, DiMarzio N, Ward J (2006) Verified passive acoustic detection of beaked whales (Mesoplodon densirostris) using bottom-mounted hydrophones in the tongue of the ocean, Bahamas. Appl Acoust 67:1091-1105

Moulins A, Rossi M, Nani B, Würtz M (2007) Aspects of the distribution of Cuvier's beaked whale (Ziphius cavirostris) in relation to topographic features in the Pelagos Sanctuary (northwestern Mediterranean Sea). J Mar Biol Assoc UK 87(1):177186

Rommel SA, Costidis AM, Fernández A, Jepson PD, Pabst DA, Mclellan WA, Houser DS, Cranford TW, Van Helden AL, Allen DM, Barros NB (2006) Elements of beaked whale anatomy and 
diving physiology and some hypothetical causes of sonar-related stranding. J Cetacean Res Manag 7:189-209

Schneider A (2003) GPS visualizer. http://www.gpsvisualizer.com. Accessed 26 May 2009

Schorr GS, Baird RW, Webster DL, McSweeney DJ, Hanson MB, Andrews RW, Barlow J (2007) Spatial distribution of Blainville's beaked whales, Cuvier's beaked whales, and short-finned pilot whales in Hawai'i using dorsal fin-attached satellite and VHF tags: implications for management and conservation. 17th biennial conference on the biology of marine mammals, Cape Town, Nov-Dec 2007

Simmonds MP, Lopez-Jurado LF (1991) Whales and the military. Nature 351:448

Tyack PL, Johnson M, Soto NA, Sturlese A, Madsen PT (2006) Extreme diving of beaked whales. J Exp Biol 209:4238-4253
Ward J, Morrissey R, Moretti D, DiMarzio N, Jarvis S, Johnson M, Tyack P, White P (2008) Passive acoustic detection and localization of Mesoplodon Densirostris (Blainville's beaked whale) vocalizations using distributed bottom-mounted hydrophones in conjunction with a digital tag (DTAG) recording. Can Acoust 36(1):60-66

Zimmer WMX, Tyack PL (2007) Repetitive shallow dives pose decompression risk in deep-diving beaked whales. Mar Mamm Sci 23:888-925

Zimmer WMX, Johnson MP, Madsen PT, Tyack PL (2005) Echolocation clicks of free-ranging Cuvier's beaked whales (Ziphius cavirostris). J Acoust Soc Am 117:3919-3927

Zimmer WMX, Harwood J, Tyack PL, Johnson MP, Madsen PT (2008) Passive acoustic detection of deep-diving whales. J Acoust Soc Am 124(5):2823-2832 